\title{
The impact of the ROPO effect in the clothing industry ${ }^{1}$
}

\author{
Barbara Mróz-Gorgoń2 ${ }^{2}$, Grzegorz Szymański ${ }^{3}$
}

\begin{abstract}
The number of Internet users in Poland is permanently increasing, the vast majority of Y generation use the Internet at least once a week, while the youngest generation (born after 2000) consider the Internet to be a part of their normal life. Shopping online should be something natural and ordinary for Internet users and the main barriers of the development of e-commerce such as security of transactions, time and cost of delivery are regarded as a standard and truism. The ROPO effect is a major problem for the rapid development of the e-commerce sector. However, the analyzed clothing industry, due to the individual characteristics of products, is a different e-commerce area than others. The obtained results indicate that about $33 \%$ of women and men use the Internet as a place to get information about clothing products. Research Online, Purchase Offline, that is, search for information, reviews, or online prices, while buying in the traditional way. The purpose of the publication is to identify the size of the ROPO effect the clothing industry. In order to meet this goal, we analyzed the results of more than 4.000 respondents who have recently purchased clothing products.
\end{abstract}

Keywords: ROPO, e-commerce, clothing industry.

JEL codes: L81, L67.

\section{Introduction}

High dynamics of changes occurring in the trade understood as economic activity, under the influence of the environment, is the result of strategies used by commercial enterprises. Turbulent environment, increased competition, development of new information technologies, as well as changes in purchaser's behaviors are the main determinants of the high dynamics of transformations in commerce understood as economic activity. New conditions put new challenges ahead of people, who manage commercial companies. By using the

\footnotetext{
${ }^{1}$ Article received 18 December 2017, accepted 24 April 2018.

${ }^{2}$ Wrocław University of Economics, Department of Marketing, 53-345 Wrocław, ul. Komandorska 118/120.

${ }^{3}$ Lodz University of Technology, Department of Management and Engineering Production, 90-924 Łódź, ul. Piotrkowska 266, grzegorz.szymanski@p.lodz.pl.
} 
Internet, as well as new solutions used by the retail sector in so-called traditional sales, commerce becomes more and more innovative. The use of online tools in commercial activity dates back to the beginning of the last decade, especially since 2003. Both websites and online stores are used here (Michalczyk, 2012 , p. 21). Increasing competition in the trade sector causes that commercial enterprises verify their strategies and make innovations. They may be partial solutions in terms of selected areas of activity or general solutions related to the radical change of the business model.

The reasons for the systematic and continuous development of e-commerce are its key advantages and popularization of the Internet and mobile devices. Today, $69 \%$ of Poles over the age of 15 use the Internet - mostly at home (96\%), less often at work (35\%). Furthermore, the majority of Internet users use the Internet every day (52\%) or several times a week (14\%) (UKE, 2015, p. 14). In 2016, there were over 32 million active SIM cards in subscription offers (59\% of the market) in Poland, i.e. 3.1 million more SIM cards than in the previous year. There were 142.4 subscribers or mobile number users per 100 inhabitants (socalled penetration rate $-142.4 \%$ ) (Telepolis, 2016). The online revolution has created the opportunity to sell in the online system, i.e. via the Internet (brand websites, online stores and other portals). Consumers acquire new skills in using the information contained in the Web, which is an important element of the ROPO effect examined in this article (i.e. Research Online, Purchase Offline).

The characteristic features for the clothing industry is delivery time and the customer who expects the goods he is looking for is available in a nearby location or has the option of returning. The clothing industry, due to its specific features, is one of the slower growth in the e-commerce sector. Customers need physical contact with the product before buying it. Therefore, it seems that the internet is the source of inspiration and information about clothing products. However, the purchase of the product, customers make in traditional clothing stores. The aim of this article is to determine the size and significance of the ROPO effect in the clothing sector. The article was based on the studies of literature on the subject (foreign and Polish), as well as on the analysis of conducted surveys with a primary nature.

\section{The essence of the ROPO effect in e-commerce}

Contemporary trade is characterized by significant dynamics of changes and a greater degree of interaction with the client. In numerous publications, during scientific conferences or meetings of business practitioners, the growing importance of mobile commerce, the increase of the importance of multi-channel purchase (introduction of the so-called omnichannel) and the key role of commercial enterprises in their traditional form of operation that can be called off-line or in-store (in another naming) are indicated (Zawadzki, 2016, p. 64). 
Competitive advantage of retail stores is connected, among others things, with the effectiveness of the realized strategy related to the store's distinguishing. Better identification of client's needs and better matching of marketing instrument are reflected in the assessment of the stores' image (Stefańska, 2011, pp. 171-181).

From a marketing perspective, it is also important to reach undecided people (Michalczyk, 2012, p. 28). In this fields, new solutions, which fulfill or oven exceed consumer expectations, are searched. Formats: pup-up store (the idea of creating surprising and unique stores that appear and operate only for a limited time - note of the author) and concept store (a store created in accordance with a certain characteristic theme as an alternative to stores in galleries - note of the author) refer to a completely different shopping characteristic than in the case of e-commerce: impulsive action based on many sensory experiences (visual, fragrant, taste, auditory). Theatricalization of the arrangement, creating a form of attractive spending time, the possibility of direct contact with the product, as well as with another person has its value and it is potentially a special feature of stationary forms of sales, especially these innovative forms (Borusiak, 2011, p. 111). This trend is strongly perceived in the clothing industry. Simultaneously, attention should be paid to the growing role of online sales in this industry - described later in this article.

ROPO effect (Research Online, Purchase Offline) is a phenomenon involving the search for information about a certain product via the Internet, and the actual purchase takes place in traditional stores. This consumer mechanism is a problem for e-commerce sector enterprises, because the Internet is merely a channel for obtaining information (Heinemann \& Gaiser, 2014, p. 150). Online stores professionally prepare their product offer, and one of its key elements is a description. A potential customer (when visiting a website) expects comprehensive information about the goods - both in terms of specification, warranty and opinions of other users. Unfortunately, the dynamically increasing range of offer from e-stores causes the problem of making a purchase decision. The selection of a certain product that will meet the customer's expectations in the highest degree becomes more and more difficult. Therefore, finalization of the buying process in a traditional store, where the seller supports the client during the search and selection process, as well as he or she helps the client to find the best product that suits his or her needs, becomes more and more popular. The ROPO phenomenon can be a big problem for e-commerce sector sellers, so solutions, aimed at the reduction of the number of "abandoned baskets," are implemented. One of the solutions is the personalization of both the offer and marketing activities, which in connection with positive emotions of recipients are able to increase the conversion. Additionally, customization can increase enterprise's income by up to $15 \%$, and the effectiveness of marketing expenses can increase by up to 30\% (Pappas, Kourouthanassis, Giannakos, \& Chrissikopoulos, 2017, pp. 972-982). Another solution is to use recommen- 
dation models and algorithms that cover many aspects. First of all, the analysis includes relations between products searched by customers. These relations help to determine client's motivations and build a set of potential products. Secondly, they determine customers' preferences regarding the features and functions of the products in order to identify products that will meet the expectations of consumers in the highest degree. Moreover, the analysis includes such categories of product's functions as: dynamic features of the product that can be observed by the user, but not by the analyst and static features that can be observed by the analyst. On the basis of data collection and consumer behavior analysis, the model identifies products that are presented to users of online stores (Qiu, Lin, \& Li, 2015, p. 451).

Another solution is to run both a physical store and an online platform in order to reach potential clients through the use of a multi-channel strategy and provide access to products via more than one distribution channel (Jang, Chang, \& Chen, 2015, p. 160). Furthermore, the transfer of online customers to the own traditional sales channel significantly reduces the impact of the analyzed ROPO effect.

The key aspect of the research carried out by the authors was to identify the size of ROPO effect in the analyzed clothing industry depending on individual demographic and social characteristics of respondents. The average value of this effect for the entire industry reached the value of $32.7 \%$, i.e. almost 3 out of 10 surveyed people, before making a purchase in a traditional store, search information about the product on the Internet. In comparison with other sectors, this value is relatively low. Perhaps this is due to the fact that clothing belongs to a group of products, which are not characterized by too many individual features. In addition to sizes and color, the most important determinants affecting shopping decisions are fashion, cut and material. However, these features are difficult to compare, because they are dependent on personal preferences and fashion. The Internet can be used to compare prices, search for product's opinions and browse various offers. The obtained ROPO value also arises from the specificity of clothing products. Online shopping is problematic for clients for several reasons. Firstly, different standards of clothing size cause difficulties in precise matching for an individual customer. For example, "L" size in one company has completely different values of individual dimensions than in another one. Therefore, an important element of the purchasing processes in the analyzed sector is to try on clothes before buying. Secondly, colors presented on the screen of a computer/smartphone may significantly differ from the actual colors. There are several stages of possible changes in the color of products: camera settings, graphic correction and parameters of the Internet user's monitor/display. The last factor is personal preferences of the consumer and comfort of use. All these aspects significantly affect the value of the ROPO effect in the clothing industry. Identification of the size of their influence may be the basis for detailed researches in the analyzed matter. 


\section{Clothing industry - characteristics and trends}

Currently, the clothing industry is one of the strongest branches of the world economy. Only in Poland, the value of sold clothing amounted to over 22 million PLN in 2013 (Omnichannel, 2015).

However, it should be emphasized that in the last few decades the clothing industry in the world was subject to significant transformations related to many factors in the business environment (Wanat, 2016, p. 271). Companies, in response to the challenges posed by today's market environment, seek new solutions and concepts that can be found in marketing strategies and policies of these companies. One of the visible trends is the use of the achievements of the corporate social responsibility (CSR) in order to create a framework for functioning in accordance with the growing market expectations. The reasons for this behavior of enterprises in the clothing industry are social problems, which are nowadays more and more significant.

The characteristic features for the clothing industry are the time needed to complete the purchase, the nearby location of the store and an affordable price (Rudnicka, 2016, pp. 21-22). Therefore, another trend (very important due to the size of the phenomenon) was the emergence and development of retail enterprises referred to as "fast fashion". These enterprises, based on mass production in short series and efficient logistics system, achieved significant market success (Wanat, 2016, p. 271). By analyzing the assumptions of both concepts (CSR and fast fashion), it can be stated that they face each other in the opposition. Nevertheless, a frequent case is to promote a "fast fashion" brand as the brand, which acts in the spirit of the corporate social responsibility.

The modern and highly competitive environment causes that the majority of enterprises, which offer products, try to ensure their quickest possible delivery to the customer. Moreover, these entities want to produce these products in the lowest possible price. The produce must be available in a convenient location, and the entire production and distribution cycle should not last longer than a few weeks (Rudnicka, 2016, p. 22). Companies, which operate in both traditional way and through the use of the Internet, try to meet these assumptions.

According to many researches, the clothing industry occupies an important place in the perception of consumers - both in the context of traditional and online shopping.

Taking into account the Pekao Bank's report, European leaders in terms of retail value of clothing and footwear market are the United Kingdom and Germany - in their case, the market value can be estimated at the level of 70-80 billion USD. (...) Poland, with a market value of approx. 10-12 billion USD, has less than $0.3 \%$ of the world market share. This value places Poland at the end of the top ten among EU countries and at the end of the third ten of all countries in the world. In accordance with the report's authors, consumer spending on clothing and footwear in Germany exceeds 70 billion EUR per year, and the 
total expenditure on these products in the new EU member states, including Poland, is about 25 billion EUR (Raport Banku Pekao, 2017).

According to the survey conducted in the period from September to December 2016 "Fashion industry in Poland 2016" (the research was carried out on a representative group of respondents: 4 focus groups, 10 in-depth interviews and 600 online interviews), the largest and the most important clothing manufacturers in Poland include: Bytom SA, LPP SA, Warmia SA, GETEX, Telimena SA, DCG SA, Vistulagroup. Reserved, House, Cropp, Mohito and Promostar brands produced by LPP with the headquarters in Gdańsk are the best example of the international success of the Polish clothing industry. Polish clothing companies achieved a significant success on the Polish and international market. They have become ambassadors of the Polish economy all over the world. According to the report, currently, the Internet is the main sales sector with the latest fashion trends. Fashion designers begin their adventure with the sale of their projects in own online stores. Some of them place their products on websites that grater amount of niche designers. The most popular website is SHOWROOM (www.shwrm.ok), where the client can find all independent bands of the Polish fashion world for women, men and even children (Wdowiak, 2016, p. 16).

Along with the growing interest in fashion, as well as the increase in sales in this industry, more and more researches deal with the problems of clothing and fashion industry. The most frequently discussed problems researched by representatives of science are, among other things: supply chain management (Bruce, Daly, \& Towers, 2004, pp. 151-170; Christopher, Peck, \& Towill, 2006, pp. 277-287; Christopher, Lowson, \& Peck, 2004, pp. 367-376), internalization of commerce in this industry (Patora-Wysocka, 2014, pp. 8-13; De Wulf, Odekerken-Schröder, \& Iacobucci, 2001, pp. 33-50), branding (Lassar, Mittal, \& Sharma, 1995, pp. 11-19; O’Cass \& Choy, 2008, pp. 341-352), CSR - corporate social responsibility (Rudnicka, 2016, pp. 21-29); innovations (Lakhani \& Panetta, 2007, pp. 97-112). Despite such a wide range of topics examined by scientists (and only some problems are cited), there is still a research gap regarding the ROPO effect in the fashion industry. This article attempts to fill this gap.

\section{Methodology of the quantitative research}

The study was conducted in cooperation between the Faculty of Organization and Management of the Technical University of Łódź and Opiniac Company, on a group of 19386 Polish Internet users at the turn of May and June 2016 (66\% of women). For clothing and footwear products, 4914 responses were received among women. A purposeful and convenient sample selection was used - by distributing a questionnaire on the popular information portal (Wirtualna Polska) and many portals of the clothing industry. The questionnaire was a re- 
search tool. An ordinal scale (single-pole, five-point scale) was used in questions concerning the consumer assessment. The choice of the survey method was determined by a relatively low cost, which was important with such a large research group. The internet application was used to download samples and the data was collected in a database. Moreover, in the case of subjective consumer assessment, the survey method has been repeatedly used by other researchers (Maciejewski, 2017, pp. 136-146), (Zapata, Isengildina-Massa, Carpio, \& Lamie, 2016). In order to examine the dependence of individual characteristics of respondents (age, sex, place of residence and frequency of using the Internet) from a variable corresponding to the utilized device (computer, smartphone, tablet), Chi-square statistics were used. On the other hand, V-Cramer coefficient, which measures the strength of relation between variables determined in a nominal scale, was used to test the correlation power. The value of a $\mathrm{V}$ coefficient is in the range $\langle 0 ; 1\rangle$. The closer is value to 0 , the smaller is strength between the tested features, and the closer is value to 1 , the greater is strength of the examined relation. In social sciences a Cramer's V value between 0 and 0.25 is often considered to indicate a weak association, a value between 0.25 and 0.35 a medium association and a value above 0.35 a strong association (Waal, 2015, p. 12).

\section{Analysis of the value and impact of the ROPO effect}

When analyzing the Internet access tool used by Internet users, in relation to the respondents' sex (Table 1 ), the following correlation was obtained $(p<0.05)$. However, the strength of this dependence is negligible (Cramer's $\mathrm{V}=0.05$ ). Nevertheless, these differences can be indicated: fewer men than women (less than 2 percentage points) use a smartphone as a device for searching clothing products on the Internet. Additionally, the obtained ROPO effect for men is slightly smaller. This indicates that men are less likely to search for information about clothing products before their purchase.

On the other hand, by taking into account the age of respondents (Table 2), the correlation with a weak strength was identified (Cramer's $\mathrm{V}=0.17$ ). This enables to say that the selection of a device depends on the age of users. A particularly noticeable trend has been identified among smartphone users, where the number of people using smartphone decreases along with aging. Among the oldest respondents (over 55 years), only $3 \%$ of them look for information about clothing products through mobile devices. Definitely more often, older people take advantage of traditional personal computers, while for young people (under 18 years), smartphones constitute a natural environment. Furthermore, by analyzing the size of the ROPO effect, it should be pointed out that the youngest respondents search information about clothing products on the Internet more often than other age groups. 
Table 1. The number of users, who search information about the product on the Internet before the purchase (broken down by sex ad used device)

\begin{tabular}{|l|c|c|}
\cline { 2 - 3 } \multicolumn{1}{c|}{} & Women (\%) & Men (\%) \\
\hline Computer & 25.54 & 25.35 \\
\hline Smartphone & 10.29 & 8.56 \\
\hline Tablet & 2.74 & 3.38 \\
\hline ROPO & 34.10 & 31.63 \\
\hline Parameters of statistical tests & \multicolumn{2}{|c|}{$\begin{array}{c}\text { Chi-square }=20.487266 \\
p=0.000036 ; d p=2 \\
\text { Cramer's V }=0.051968\end{array}$} \\
\hline
\end{tabular}

Source: own study based on researches conducted in cooperation with Opiniac Company.

Table 2. The number of users, who searched for product information before the purchase in a traditional store (broken down into age and used device)

\begin{tabular}{|c|c|c|c|c|c|c|}
\hline & $\begin{array}{c}\text { Below } 18 \\
(\%)\end{array}$ & $18-24(\%)$ & $25-33(\%)$ & $34-42(\%)$ & 43-55 (\%) & $\begin{array}{c}\text { Over } 55 \\
(\%)\end{array}$ \\
\hline Computer & 27.02 & 25.71 & 23.23 & 26.02 & 26.84 & 31.00 \\
\hline Smartphone & 16.99 & 12.91 & 10.48 & 7.72 & 4.23 & 3.06 \\
\hline Tablet & 3.34 & 2.65 & 3.51 & 2.38 & 2.76 & 2.62 \\
\hline ROPO & 41.50 & 34.71 & 31.77 & 32.32 & 32.17 & 32.62 \\
\hline $\begin{array}{l}\text { Parameters of } \\
\text { statistical tests }\end{array}$ & \multicolumn{6}{|c|}{$\begin{array}{c}\text { Chi-square }=1341.734409 \\
p=<0.000001 ; d p=10 \\
\text { Cramer's V }=0.169877\end{array}$} \\
\hline
\end{tabular}

Source: own study based on researches conducted in cooperation with Opiniac Company.

A similar correlation power as in the case of age effects was obtained for the variable in the form of the frequency of Internet usage (Table 3). People, who regularly check information on the Internet, are more likely to take advantage of mobile devices (approx. 9\%) than the rest of the respondents. A significant difference was also found in the analysis of the ROPO effect, where almost $40 \%$ of active Internet users check information about clothing products on the Internet, and only $26 \%$ of people, who use the Internet a few times a week. It is hard to identify the causes of these results, so supplementary researches should be conducted.

Despite the fact that there is a correlation between the place of residence and the device $(p<0.05)$, its strength is negligible (Cramer's $\mathrm{V}=0.07$ ) (Table 4 ). However, it can be pointed out that people living in rural areas and urban areas with the size of 100-199 thousand people use a computer to search for information about clothing products more often than others. On the other hand, the 
Table 3. The number of users, who searched for product information before the purchase in a traditional store (broken down into age and used device)

\begin{tabular}{|l|c|c|c|}
\hline & $\begin{array}{c}\text { Every day or almost } \\
\text { every day (\%) }\end{array}$ & $\begin{array}{c}\text { Several times a week } \\
\text { (\%) }\end{array}$ & $\begin{array}{c}\text { Several times } \\
\text { a month and less } \\
\text { often (\%) }\end{array}$ \\
\hline Computer & 23.54 & 21.63 & 30.43 \\
\hline Smartphone & 9.01 & 3.37 & 2.02 \\
\hline Tablet & 2.61 & 2.88 & 1.89 \\
\hline ROPO & 39.61 & 26.44 & 31.43 \\
\hline $\begin{array}{l}\text { Parameters of statis- } \\
\text { tical tests }\end{array}$ & \multicolumn{3}{|c|}{$\begin{array}{c}\text { Chi-square }=629.683132 \\
p=<0.000001 ; d p=4 \\
\text { Cramer's V }=0.179809\end{array}$} \\
\hline
\end{tabular}

Source: own study based on researches conducted in cooperation with Opiniac Company.

Table 4. Number of users, who searched for information about the product on the Internet before buying in a traditional store (broken down by the size of place of residence and the equipment used)

\begin{tabular}{|c|c|c|c|c|c|c|c|}
\hline & $\begin{array}{c}\text { Village } \\
(\%)\end{array}$ & $\begin{array}{l}\text { Town up } \\
\text { to } 20,000 \\
\text { residents } \\
(\%)\end{array}$ & $\begin{array}{l}20,000- \\
-49,000 \\
\text { residents } \\
(\%)\end{array}$ & $\begin{array}{c}50,000- \\
-99,000 \\
\text { residents } \\
(\%)\end{array}$ & $\begin{array}{l}100,000- \\
-199,000 \\
\text { residents } \\
(\%)\end{array}$ & $\begin{array}{l}200,000- \\
-500,000 \\
\text { residents } \\
(\%)\end{array}$ & $\begin{array}{l}\text { Over } \\
500,000 \\
\text { residents } \\
(\%)\end{array}$ \\
\hline Computer & 28.05 & 23.94 & 24.35 & 24.94 & 28.37 & 24.43 & 24.59 \\
\hline Smartphone & 10.37 & 10.62 & 9.50 & 10.47 & 7.65 & 9.18 & 8.84 \\
\hline Tablet & 1.95 & 3.67 & 1.73 & 2.23 & 2.21 & 3.28 & 3.59 \\
\hline ROPO & 35.61 & 32.82 & 31.61 & 34.30 & 35.21 & 32.30 & 32.14 \\
\hline $\begin{array}{l}\text { Parameters } \\
\text { of statistical } \\
\text { tests }\end{array}$ & \multicolumn{7}{|c|}{$\begin{array}{c}\text { Chi-square }=268.439467 \\
p=<0.000001 ; d p=12 \\
\text { Cramer's V }=0.071308\end{array}$} \\
\hline
\end{tabular}

Source: own study based on researches conducted in cooperation with Opiniac Company.

ROPO effect had the smallest value in towns from 20 to 40 thousand inhabitants. However, the differences in the ROPO value in particular areas are not significant - in extreme cases, they amount to 4 percentage points.

The last analyzed area is an assessment of the extent, to which information found on the Internet influenced the final purchase decision made by respondents (Table 5). Respondents rated in a scale from 1 to 5 , where 1 meant a complete lack of influence on the purchase of a clothing product, and 5 meant a very significant impact of online information on the purchase of an offline product. The overall rating (4.08) indicates the high impact of online information in the 
analyzed clothing industry. This may indicate the professional presentation of clothing, value of information and preparation of e-commerce platforms in the clothing industry. The highest differences compared to the average value were obtained for people, who use the Internet less than a few times a week (3.22).

Table 5. Assessment of the extent to which the information found on the Internet influenced the final purchase decision made by the respondents

\begin{tabular}{|l|c|c|}
\cline { 2 - 3 } \multicolumn{1}{c|}{} & Rating (1-5) & $\begin{array}{c}\text { Deviation from the } \\
\text { overall average (4.08) }\end{array}$ \\
\hline Women & 4.08 & 0 \\
\hline Men & 4.07 & -0.01 \\
\hline Under 18 years old & 3.86 & -0.22 \\
\hline 18-24 years old & 4.07 & -0.01 \\
\hline 25-33 years old & 4.15 & 0.07 \\
\hline 34-42 years old & 4.14 & 0.06 \\
\hline $43-55$ years old & 4.04 & -0.04 \\
\hline Over 55 years old & 3.90 & -0.18 \\
\hline Every day or almost every day & 4.11 & 0.03 \\
\hline A few times a week & 3.93 & -0.15 \\
\hline Less often & 3.22 & -0.86 \\
\hline Village & 4.04 & -0.04 \\
\hline Town up to 20.000 residents & 4.08 & 0 \\
\hline 20.000-49.000 residents & 4.04 & -0.04 \\
\hline $50.000-99.000$ residents & 4.13 & 0.05 \\
\hline $100.000-199.000$ residents & 4.08 & 0 \\
\hline 200.000-500.000 residents & 4.02 & -0.06 \\
\hline Over 500.000 residents & 4.14 & 0.06 \\
\hline
\end{tabular}

Source: own study based on researches conducted in cooperation with Opiniac Company.

\section{Conclusions}

The ROPO effect is one of the significant problems of the e-commerce sector. However, the analyzed clothing industry, due to the individual characteristics of products, is a different e-commerce area than others. The obtained results indicate that about $33 \%$ of women and men use the Internet as a place to get information about clothing products. The most commonly used device is a personal 
computer, although among the youngest respondents (under 18), almost 17\% use a smartphone. There is also a dependence that the number of active users of mobile devices decreases with age. This results from a relatively innovative solution - not very common among elderly people. The overall high evaluation of the impact of information found on the Internet to make a purchase decision confirms the systematic increase in the popularity of e-commerce in the clothing industry. Furthermore, the analysis of the obtained results shows that there is not significant relation between sex, size of the place of residence and frequency of Internet use. Additional in-depth researches should be carried out in order to identify the reasons of the indicated trends.

\section{References}

Borusiak, B. (2011). Innowacyjne formaty handlu detalicznego. Zeszyty Naukowe Uniwersytetu Ekonomicznego w Poznaniu, 184, 114-124.

Bruce, M., Daly, L., \& Towers, N. (2004). Lean or agile: a solution for supply chain management in the textiles and clothing industry?. International Journal of Operations \& Production Management, 24(2), 151-170.

Christopher, M., Peck, H., \& Towill, D. (2006). A taxonomy for selecting global supply chain strategies. The International Journal of Logistics Management, 17(2), 277-287.

Christopher, M., Lowson, R., \& Peck, H. (2004). Creating agile supply chains in the fashion industry. International Journal of Retail \& Distribution Management, 32(8), 367-376.

De Wulf, K., Odekerken-Schröder, G., \& Iacobucci D. (2001 October). Investments in consumer relationships: a cross-country and cross-industry exploration. Journal of Marketing, 65(4), 33-50.

Heinemann, G. \& Gaiser, C. (2014). Social local mobile, the future of location-based services. London: Springer,

Jang, Y.-T., Chang, S. E., \& Chen, P.-A. (2015). Exploring social networking sites for facilitating. Multimedia Tools and Applications, 74(1), 159-178.

Lakhani, K. R. \& Panetta, J. A. (2007). The principles of distributed innovation. Innovations: Technology, Governance, Globalization, 2(3), 97-112.

Lassar, W., Mittal, B., \& Sharma, A., (1995) Measuring customer-based brand equity. Journal of Consumer Marketing, 12(4), 11-19.

Maciejewski, G. (2017). Formaty handlu detalicznego w Polsce w ocenie konsumentów. Studia Ekonomiczne, 316, 136-146.

Michalczyk, L. (2012). Perspektywy rozwoju e-commerce w Polsce. Handel Wewnętrzny, 6(341), 21-29.

O'Cass, A., Choy, E. (2008). Studying Chinese generation Y consumers' involvement in fashion clothing and perceived brand status. Journal of Product \& Brand Management, 17(5), 341-352. 
Omnichannel. (2015). Raport z badania poziomu wielokanałowości w branży fashion. Retrieved from https://www.unity.pl/wp-content/uploads/2015/09/Raportomnichannel2015-fashion.pdf

Pappas, I. O., Kourouthanassis, P. E., Giannakos, M. N., \& Chrissikopoulos, V. (2017). Sense and sensibility in personalized e-commerce: how emotions rebalance the purchase intentions of persuaded customers. Psychology \& Marketing, 34(10), 972-986.

Patora-Wysocka, Z. (2014). Change dynamics in the process of internationalisation of clothing and textile enterprises. Fibres \& Textiles in Eastern Europe, 5(107), 8-13.

Qiu, J., Lin, A., \& Li, Y. (2015). Predicting customer purchase behavior in the e-commerce context. Electronic Commerce Research, 15(4), 427-452.

Raport Banku Pekao. (2017). Polski rynek odzieżowo-obuwniczy będzie systematycznie rósł do 2020 r. Retrieved from https://www.money.pl/gospodarka/wiadomosci/ artykul/lpp-hm-rynek-odziezowy,203.0,2304203.html

Rudnicka, A. (2016). Innowacyjna i odpowiedzialna branża odzieżowa. Journal of Reverse Logistic, 4(21), 21-29.

Stefańska, M. (2011). Tożsamość a wizerunek w handlu detalicznym - implikacje dla skuteczności realizowanej strategii pozycjonowania. Zeszyty Naukowe Uniwersytetu Ekonomicznego w Poznaniu, 177, 31-35.

Telepolis. (2016). GUS: dane dotyczące rynku telekomunikacyjnego w 2016 roku. Retrieved from http://www.telepolis.pl/wiadomosci/gus-dane-dotyczace-rynkutelekomunikacyjnego -w-2016-roku,2.3,38085.html?cp=1

UKE. (2015). Rynek usług telekomunikacyjnych w Polsce w 2015 roku. Raport z badania klientów indywidualnych. Retrieved from https:/www.uke.gov.pl/files/?id_ plik=21543

Waal, Ton de. (2015). Statistical matching: experimental results and future research questions. Statistics Netherlands, 19.

Wanat, T. (2016). Wpływ ceny i asortymentu na częstotliwość wizyt w sklepach typu fast fashion. W: M. Sławińska (Ed.), Handel we współczesnej gospodarce. Nowe wyzwania (pp. 271-282). Poznań: Uniwersytet Ekonomiczny w Poznaniu.

Wdowiak, Ł. (2016). Branża modowa w Polsce 2016 - Raport. Strategia, badania rynku, Warszawa. Retrieved from https://strategaresearch.pl/branza-modowa-wpolsce-2016.

Zawadzki, T. (2016). Innowacje marketingowe w tradycyjnych przedsiębiorstwach handlowych na przykładzie stacji paliw. W: M. Sławińska (Ed.), Handel we współczesnej gospodarce. Nowe wyzwania (pp. 64-72). Poznań: Uniwersytet Ekonomiczny w Poznaniu.

Zapata, S. D., Isengildina-Massa, O., \& Carpio, C. E., Lamie, R. D. (2016). Does e commerce help farmers' markets? Measuring the impact of market maker. Journal of Food Distribution Research, 47(2), 1-18. 